\title{
Impact of ryegrass selection and paddock history on clover establishment in new dairy pasture
}

\author{
P.J. GERARD ${ }^{1}$, B.M. COOPER ${ }^{2}$, T.M. EDEN ${ }^{1}$, S.A. HOWLETT ${ }^{1}$, P.M.S. LANE ${ }^{3}$, \\ K.A. PANCKHURST ${ }^{2}$, B.E. WILLOUGHBY ${ }^{4}$ and D.J. WILSON ${ }^{1}$ \\ ${ }^{1}$ AgResearch, Ruakura Research Centre, Private Bag 3123, Hamilton \\ ${ }^{2}$ AgResearch, P.O. Box 23, Kerikeri \\ ${ }^{3}$ Ballance Agri-Nutrients P.O. Box 390, Cambridge \\ ${ }^{4}$ AgResearch, now 8 Bond St, Hamilton 3216 \\ pip.gerard@agresearch.co.nz
}

\begin{abstract}
The effect of diploid and tetraploid ryegrass on clover establishment in new pasture following maize, turnips or grass was investigated in Northland and Waikato in autumn 2004. White clover seedling establishment at 4 weeks was $12-20 \%$ higher with tetraploid ryegrass compared to diploid ryegrass, and lowest clover seedling numbers were in the ex-grass paddocks. Production data from the Northland site showed that in December 2004, the ex-maize and exturnip paddocks, respectively, had $54 \%$ and $79 \%$ more pasture than ex-grass paddocks. Reducing the diploid ryegrass sowing rate from 16 to $8 \mathrm{~kg} / \mathrm{ha}$ did not impact on its dry matter production. The benefit of successful establishment appeared to last with Year 3 ex-crop pastures in Waikato having more clover, fewer weeds, and higher autumn production compared to ex-grass pastures, and the tetraploid ryegrass having more clover than diploid pastures.
\end{abstract}

Keywords: clover establishment, break crops, tetraploid ryegrass

\section{Introduction}

White clover is important in New Zealand, but its ability to contribute to farm profitability is being compromised by current establishment and management techniques, along with the arrival of clover root weevil. Grass to grass pasture renovation using direct-drilling techniques does not favour clover establishment as limited seed bed preparation and excessive sowing depth can lead to low seedling emergence (Brock \& Kane 2003). Seedlings are also vulnerable to the resident pests and diseases which contributed to the deterioration of the old pasture, in particular, clover root weevil and nematodes. Their vulnerability is further increased by competition from perennial ryegrass (Lolium perenne) containing the fungal endophyte Neotyphodium lolii which, by providing protection against many resident pests, increases tiller density at the expense of clover (Eerens et al. 2001). There are, however, advantages associated with pasture renewal using direct-drilling over cultivation, such as less preparation time, lower soil erosion, greater control of perennial weeds and less time out of production (Hume \& Lyons 1993).

Two field trials were undertaken to demonstrate the effects of ryegrass attributes (ploidy, endophyte selection and sowing rate) on red and white clover establishment in paddocks with contrasting pre-sowing management. This paper reports on the impacts of ryegrass sowing rate, ryegrass ploidy and paddock history on white clover in these demonstration trials.

\section{Methods \\ Layout}

The treatment layout was a split-plot design with three paddocks (ex-turnips, ex-maize and ex-pasture) each divided into five strips to which five ryegrass treatments were allocated. Each strip was split into plots, which were sown with one of two clover treatments.

The study compared contrasting ryegrass types: a diploid ryegrass (cv. 'Bronsyn') and a tetraploid ryegrass (cv. 'Quartet'), each infected with either wildtype (Standard) or AR1 fungal endophyte. The diploid ryegrass was sown at $16 \mathrm{~kg} / \mathrm{ha}$ and the tetraploid at 20 $\mathrm{kg} / \mathrm{ha}$ to account for differing seed size. A fifth treatment consisted of diploid Standard endophyte seed sown at 8 $\mathrm{kg} / \mathrm{ha}$ (half rate). Seed viability was $95 \%$ or greater. The clover treatments were sown at $4 \mathrm{~kg} / \mathrm{ha}$ and consisted of either treated (Superstrike ${ }^{\circledR}$ ) white clover (cvs. 'Grasslands Kopu II' and 'Grasslands Tribute') or a 50:50 mix by weight of red (cvs. 'Grasslands Collenso' and 'Grasslands Sensation') and the two white clovers. The remainder of the paddocks surrounding each site was sown with cvs. 'Bronsyn' (Standard endophyte) and 'Grasslands Kopu II'.

\section{Site details}

The Waikato trial on a Hamilton clay loam at Horsham Downs, near Hamilton, was sown in late April 2004. The ex-turnip and maize paddocks had been rotary cultivated and rolled while the ex-pasture paddock had been sprayed with Buster ${ }^{\mathrm{TM}}$ (gluphosinate) followed by glyphosate at label rates. Each of the five ryegrass strips was $12 \mathrm{~m}$ wide (two drill widths of a John Deere 750A 
Effect of diploid ryegrass sowing rate and ryegrass ploidy on mean number of clover seedlings $/ \mathrm{m}^{2}$ at Week 4 after sowing at Northland and Waikato sites, and numbers of ryegrass seedlings $/ \mathrm{m}$ row at Week 4 and clovers at Week 8 (Waikato site only).

\begin{tabular}{lcccc}
\hline & $\begin{array}{c}\text { Northland } \\
\text { White clover }\end{array}$ & \multicolumn{2}{c}{ Waikato } & White clover \\
Week & 4 & 4 & 8 & 4 \\
\hline $16 \mathrm{~kg} / \mathrm{ha}$ & 485 & 153 & 180 & 79 \\
$8 \mathrm{~kg} / \mathrm{ha}$ & 569 & 160 & 213 & 58 \\
Diploid & 484 & 111 & 176 & 77 \\
Tetraploid & 584 & 124 & 188 & 62 \\
SED & 82 & 16 & 16 & 6 \\
P values & & & 0.07 & $<0.01$ \\
Sowing rate & 0.33 & 0.68 & 0.31 & 0.25 \\
Ploidy & 0.08 & 0.08 & \\
\hline
\end{tabular}

drill) by $90 \mathrm{~m}$ long and was divided into six plots which were randomly allocated to the two clover treatments. Clover seed was broadcast using a manually-operated seed spreader, harrowed, then rolled with a Cambridge roller. Light rain followed 3 days later providing good conditions for seedling germination. Grazing commenced 45 days after sowing.

The Northland trial on a Waimate North clay loam at Waimate North, near Kerikeri, was sown in early May 2004. The ex-turnips, ex-maize and ex-pasture (kikuyu) blocks had all been pre-cultivated. The ryegrass strips were $25 \mathrm{~m}$ wide and $50 \mathrm{~m}$ long and were sown using a Duncan roller drill ('V'-drill, harrow and Cambridge roller combined). Each strip was split lengthways into two plots (a total of 10 plots) and broadcast, harrowed and rolled with either white clover or the red and white clover mix using the Duncan roller drill.

\section{Assessments}

Clover seedlings were counted in 15 randomly placed quadrats $(20 \times 10 \mathrm{~cm})$ along drill rows within each plot at Week 4 and Week 8 (Waikato only) post-sowing. At the Waikato site ryegrass seedlings were counted along drill rows in the above quadrats at Week 4. As the quadrats were not random in orientation, ryegrass establishment was calculated as seedlings $/ \mathrm{m}$ row rather than seedlings $/ \mathrm{m}^{2}$.

Standing herbage mass ( $\mathrm{kg} \mathrm{DM} / \mathrm{ha})$ was assessed in the Waikato ex-turnip block at Week 8 by cutting three $0.3 \mathrm{~m}^{2}$ quadrats per plot. There was insufficient growth in the ex-grass and ex-maize paddocks to carry out a full assessment of grass treatment differences in the saturated soil conditions without damaging plots, so sampling was limited to six quadrats from each ryegrass strip.

Subsequent pasture assessments varied between sites. Pre-grazing herbage mass was assessed at the Northland site in September and December 2004 and
March, April and June 2005, using a calibrated rising plate meter. Herbage composition was assessed by taking hand-clipped samples along where the plate meter readings were made, bulking them together, and then dissecting a subsample.

At the Waikato site, immediate pre-grazing standing herbage mass was assessed by rising plate meter. Seasonal herbage composition in each plot was determined by visual scores of \% grass, clover and broadleaf weed cover in five randomly-placed $64 \times 33$ $\mathrm{cm}$ frames. Five cuts approximately $3 \mathrm{~cm}$ above ground level were taken from these frames at each site to calibrate assessments. However, the assessments were carried out at variable times between grazings during the first 2 years after establishment, meaning these data could not be statistically analysed or compared with Northland data. Only in Year 3 were measurements taken immediately before grazing and as the paddock grazing dates differed widely, they were assessed on a seasonal basis (spring 2006, summer 2006/07 and autumn 2007). Red clover did not persist at the Waikato site and by Year 3 all clover in the visual scores in both the white and red clover mix and white clover only plots could be assumed to be white clover.

Soil fertility was assessed at the Waikato site by bulking 20,2.5 $\mathrm{cm}$ diameter soil plugs taken to a depth of $5 \mathrm{~cm}$ from each site on 26 July 2004, followed by commercial laboratory analyses.

Soil macrofauna (e.g. grass grub larvae) were assessed in June 2005 by taking ten, $10 \mathrm{~cm}$ diameter soil cores to a depth of at least $10 \mathrm{~cm}$ from each plot and hand-sorting in the field.

Although only the results for the diploid Standard endophyte sowing rate effects, white clover and ryegrass ploidy are being reported in this paper, the probabilities presented were calculated using all treatments. A split-plot analysis of variance was carried out with paddock history as the unreplicated main plot 
Table 2 Effect of diploid ryegrass sowing rate and ryegrass ploidy on mean pasture DM production before grazing (kg/ha) at the Northland and Waikato sites, Dec 2004-June 2007.

\begin{tabular}{lrrrrrrrr}
\hline & \multicolumn{3}{c}{ Northland (Year 1) } & \multicolumn{3}{c}{ Waikato (Year 3) } \\
& Dec 04 & Mar 05 & Apr 05 & Jun 05 & Spr 06 & Sum 07 & Aut 07 & Win 07 \\
\hline 16 kg/ha & 3650 & 2460 & 2060 & 3240 & 3090 & 2800 & 3480 & 2690 \\
8 kg/ha & 3400 & 2460 & 2060 & 3140 & 3280 & 2800 & 3620 & 2650 \\
Diploid & 3620 & 2470 & 2050 & 3170 & 3130 & 2770 & 3410 & 2670 \\
Tetraploid & 3310 & 2360 & 1920 & 2760 & 3140 & 2530 & 3220 & 2590 \\
SED & 214 & 168 & 52 & 165 & 93 & 83 & 89 & 142 \\
P values & & & & & 0.81 & 0.60 & 0.16 & 0.81 \\
Sowing rate & 0.27 & 1.0 & 0.93 & 0.57 & 0.08 & 0.02 & $<0.01$ & 0.86 \\
Ploidy & 0.07 & 0.37 & 0.01 & 0.03 & & & & \\
\hline
\end{tabular}

and as a factorial randomised block on the treatments. The ploidy comparisons excluded the diploid Standard endophyte sown at $8 \mathrm{~kg} / \mathrm{ha}$.

\section{Results and Discussion}

\section{Site differences}

At Week 4, overall white clover seedling numbers at the Northland site were more than twice those at Waikato $(\mathrm{P}<0.001)$ (Table 1). The better establishment in Northland is likely to be associated with precultivation of all seedbeds, use of the Duncan roller drill, and possibly fewer clover pests and diseases in the ex-pasture paddock following kikuyu compared with ryegrass/white clover pasture.

The excellent seedling establishment was not maintained in Northland, however, and from December 2004 onwards white clover content was less than $15 \%$ of DM. The Northland site was a beef to dairy farm conversion and early grazing spells were long (around 10 weeks) due to a lack of fencing. In addition, Northland experienced severe drought with March and April 2005 rainfall at 27 and $21 \mathrm{~mm}$, respectively, (cf. 25 year average 115 and $150 \mathrm{~mm}$ ). In contrast, rainfall was normal and grazing was closely managed in the first year at the Waikato site. Although wet conditions and risk of pugging meant stock did not graze the new pastures until 45 days after sowing, the pastures never became rank with grazing intervals as short as 9 days on the ex-turnip paddock in early summer 2005.

\section{Ryegrass sowing rate}

Reducing the sowing rate of the diploid Standard endophyte ryegrass from the standard of 16 to $8 \mathrm{~kg} / \mathrm{ha}$ had no long-term effect on pasture composition. While the half-rate plots at the Waikato site had 27\% fewer ryegrass seedlings than diploid Standard endophyte plots at Week 4 (Table 1), by Week 8 post-sowing there was no significant difference in DM production between the treatments ( 461 vs. $423 \mathrm{~kg} / \mathrm{ha}, \mathrm{P}=0.46$ ). Nor were there any statistical differences observed in mean pasture DM production at the Northland site in Year 1 or the Waikato site in Year 3 (Table 2). Sowing rate had no effect on levels of broad-leaved weeds (data not presented).

These results support earlier work (Cullen 1958; Black et al. 2006). These authors also found lower ryegrass sowing rates in spring resulted in a higher proportion of white clover in pasture. However, while diploid Standard endophyte plots sown at half the usual rate tended to have more white clover seedlings during establishment (Table 1) and clover content at 6 months (Table 3) than those at the usual rate, no significant differences were detected.

\section{Ryegrass ploidy}

There was no significant difference in white clover seedling counts between the diploid and tetraploid plots (Table 1) nor in initial dry matter (DM) production (452 vs. $439 \mathrm{~kg} / \mathrm{ha}, \mathrm{P}=0.662$ ) at Week 8 post-sowing at the Waikato site.

Over the year following establishment at the Northland site, diploid plots produced significantly more DM before grazing than did the tetraploid plots (April $(6 \%, \mathrm{P}<0.01)$ and June $(15 \%, \mathrm{P}<0.05)$ ) (Table $2)$. The diploid plots also produced significantly more DM than the tetraploid plots in the third year after establishment at the Waikato site in both summer $(10 \%$, $\mathrm{P}<0.05)$ and autumn $(6 \%, \mathrm{P}<0.01)$.

Overall, white clover content in the pooled tetraploid plots at the Northland site was almost double that of the diploid plots in March 2005, 10 months after sowing (Table 3) albeit at low levels because of the drought. Similarly, at each assessment in Year 3 at the Waikato site, the pasture white clover content in tetraploid plots was approximately $10 \%$ above that observed in the diploid plots (Table 3 ). While the results in this trial were confounded with tetraploid seedling densities at around $20 \%$ less than diploid densities (Table 1), Westwood \& Norriss (1999) had similar results using the same cultivars. They considered this likely to be 
Table 3 Effect of diploid ryegrass sowing rate and ryegrass ploidy on the percentage of clover ${ }^{1}$ at the Northland and Waikato sites Dec 2004 - June 2007.

\begin{tabular}{lrrrrrrrr}
\hline & \multicolumn{3}{c}{ Northland (Year 1, \% DM) } & \multicolumn{4}{c}{ Waikato (Year 3, \% cover) } \\
& Dec 04 & Mar 05 & Apr 05 & Jun 05 & Spr 06 & Sum 07 & Aut 07 & Win 07 \\
\hline 16 kg/ha & 5.8 & 4.0 & 2.5 & 12.2 & 27.9 & 25.2 & 18.6 & 17.8 \\
8 kg/ha & 10.7 & 6.4 & 1.7 & 12.3 & 22.1 & 21.8 & 16.1 & 23.4 \\
Diploid & 6.4 & 3.9 & 1.9 & 10.4 & 25.1 & 26.0 & 21.1 & 20.0 \\
Tetraploid & 8.6 & 7.5 & 1.4 & 12.9 & 34.9 & 37.0 & 32.7 & 29.7 \\
SED & 2.4 & 2.2 & 1.1 & 3.2 & 6.0 & 4.2 & 2.4 & 4.1 \\
P values & & & & & & & & \\
Sowing rate & 0.08 & 0.30 & 0.48 & 0.98 & 0.05 & $<0.01$ & $<.001$ & 0.03 \\
Ploidy & 0.25 & $<0.05$ & 0.54 & 0.34 & 0.03 & 0.24 \\
\hline
\end{tabular}

${ }^{1}$ Northland, \% white clover DM; Waikato, \% white clover cover

Table 4 Effect of paddock history on mean pre-grazing pasture DM production and the percentage of clover and broad-leaved weeds at the Northland and Waikato sites, Dec 2004 - June 2007.

\begin{tabular}{|c|c|c|c|c|c|c|c|c|}
\hline & \multicolumn{4}{|c|}{ Northland (Year 1) } & \multicolumn{4}{|c|}{ Waikato (Year 3) } \\
\hline & Dec 04 & Mar 05 & Apr 05 & Jun $^{1} 05$ & Spr 06 & Sum 07 & Aut 07 & $W_{i n}^{2} 07$ \\
\hline \multicolumn{9}{|c|}{ DM (kg/ha) } \\
\hline Ex-turnip & 4280 & 2640 & 2060 & 2770 & 3100 & 2650 & 3740 & 2710 \\
\hline Ex-maize & 3680 & 2290 & 2180 & 3230 & 3150 & 2640 & 3430 & \\
\hline Ex-grass & 2390 & 2340 & 1770 & & 3240 & 2770 & 2960 & 2560 \\
\hline \multicolumn{9}{|l|}{$\%$ clover $^{3}$} \\
\hline Ex-turnip & 2.5 & 2.89 & 0.27 & 6.0 & 33.9 & 25.6 & 18.4 & 18.0 \\
\hline Ex-maize & 15.2 & 12.30 & 4.04 & 17.5 & 35.9 & 36.9 & 27.2 & \\
\hline Ex-grass & 6.5 & 2.38 & 0.57 & & 15.5 & 26.2 & 28.5 & 31.1 \\
\hline$\%$ weeds & - & - & - & - & & & & \\
\hline Ex-turnip & - & - & - & - & 0.2 & 1.1 & 0.5 & 0.4 \\
\hline Ex-maize & - & - & - & - & 2.3 & 5.7 & 2.2 & \\
\hline Ex-grass & - & - & - & - & 4.8 & 9.2 & 9.5 & 7.2 \\
\hline
\end{tabular}

${ }^{1}$ Ex-grass site oversown by farmer to maintain farm production

${ }^{2}$ Ex-maize site not sampled as flooded

${ }^{3}$ Northland, \% white clover DM; Waikato, \% white clover cover

associated with tiller characteristics ('Quartet', the tetraploid cultivar, is more upright and less densely tillered than 'Bronsyn', the diploid cultivar) and that clover may be less severely selected by grazing animals because of the enhanced palatability of tetraploids compared to diploid cultivars.

\section{Influence of paddock history}

When all clover seedling data from the two sites were combined, paddock history appeared to have a large effect on seedling numbers at 4 weeks post sowing, with around half the number present in the ex-grass paddocks $\left(215 / \mathrm{m}^{2}\right)$ compared to ex-turnips $\left(395 / \mathrm{m}^{2}\right)$ and ex-maize $\left(438 / \mathrm{m}^{2}\right)$. However, with only two sites, these differences were not statistically significant (SED $=84, \mathrm{P}=0.20$ ).
Nevertheless, these results and the remaining unreplicated and therefore observational paddock history results (Table 4) do reinforce the importance of paddock history. The use of a break crop before pasture renewal, especially if selective herbicides are used, can greatly aid seedbed preparation and reduce carryover of existing weed, disease and pest problems into new pastures. For example, in June 2005, the ex-grass paddock at the Waikato site had carryover populations of grass grub larvae $\left(21 / \mathrm{m}^{2}\right)$, white-fringed weevil larvae $\left(17 / \mathrm{m}^{2}\right)$ and black beetle adults $\left(3 / \mathrm{m}^{2}\right)$ while the other two paddocks coming out of non-host crops had none of these pests. Pre- grazing pasture yield in the ex-turnip paddock ranged from 13 to $79 \%$ more than that in the ex-grass paddock in the year following establishment at the Northland site (Table 4). At the Waikato site in Year 
3, DM production was similar across paddocks, with the exception of autumn when the ex-turnip paddock appears to have around 26\% more DM than the exgrass paddock (Table 4). In contrast, the deterioration in pasture quality in terms of broad-leaved weeds (Table 4) and annual weed grasses in the Waikato exgrass paddock was such that it was put into a crop the following spring.

Better seedbed preparation, reduced weed, disease and pest burdens and alterations in soil fertility are likely to have contributed to the better performance of the ex-crop pastures compared to the ex-grass. The ex-turnip paddock at the Waikato site had higher $\mathrm{P}$ (63 ppm) and lower $\mathrm{Mg}$ (14 MAF QT) readings than the ex-maize (P 39, Mg 31) and ex-grass paddocks (P 34, Mg 31). While these levels are all more than adequate and were unlikely to have any effect on initial seedling establishment and pasture growth, the exturnip paddocks would have been heavily grazed and therefore would have a higher $\mathrm{N}$ loading. Maize crops generally lead to lower residual soil $\mathrm{N}$, which shifts the competitive balance towards clovers in subsequent new pastures. This is the most likely explanation for the exmaize paddocks at Northland having more clover than the ex-turnips and ex-grass in the first year (Table 4).

\section{Conclusions}

The results from these trials show that ryegrass cultivar selection impacts on clover levels in pasture. With a vigorous diploid ryegrass, better clover establishment can be achieved at half the usual sowing rate with no detrimental effects on pasture production. The results also support observations that re-establishing pasture after a crop will reduce pest densities, leading to improvements in clover establishment, pasture quality, productivity and persistence, along with farm profitability.

\section{ACKNOWLEDGEMENTS}

This project was undertaken for the Northland Clover Pest Interest Group and NZ Clover Root Weevil Action Group, with the able co-ordination by Helen Moodie, NZ Landcare Trust. We also thank Henderson's Farms and Neville Rule for allowing us to run trials on their farms and Catherine Cameron for the statistical analyses. The project was supported by MAF Sustainable Farming Fund, AGMARDT and Pasture Partners.

\section{REFERENCES}

Black, A.D.; Moot, D.J.; Lucas, R.J. 2006. Spring and autumn establishment of Caucasian and white clovers with different sowing rates. Grass and Forage Science 61: 430-441.

Brock, J.L.; Kane, G.J. 2003. Variability in establishing white clover in pastures on farms. Proceedings of the New Zealand Grassland Association 65: 223-228.

Cullen, N.A. 1958. Pasture establishment studies at Invermay Research Station. Proceedings of the New Zealand Grassland Association 20: 138-147.

Eerens, J.P.J.; Crush, J.R.; Woodward, S.L.; Macdonald, K.A.; Carter, W.A. 2001. Milksolids production from different combinations of perennial ryegrass and white clover cultivars: I. Trial design and pasture performance. Proceedings of the New Zealand Grassland Association 63: 91-96.

Hume, D.E.; Lyons, T.B. 1993. Methods of establishing tall fescue and ryegrass in a dryland environment. Proceedings of the New Zealand Grassland Association 55: 105-111.

Westwood, C.T.; Norriss, M.G. 1999. Liveweight changes in lambs grazing six perennial ryegrass cultivars. Proceedings of the New Zealand Grassland Association 61: 31-35. 